\title{
De discriminerende werking van de algemenevoorwaardenafdeling
}

\author{
Mr. L.M. van Bochove en mr. T.J. de Graaf*
}

\begin{abstract}
1 Inleiding
Art. 6:247 lid 2 BW bepaalt dat de hele algemenevoorwaardenafdeling niet van toepassing is op 'overeenkomsten tussen partijen die handelen in de uitoefening van een beroep op bedrijf en die niet beide in Nederland gevestigd zijn, (...) ongeacht het recht dat de overeenkomst beheerst'. ${ }^{1}$ Als een van beide partijen in Nederland gevestigd is en de ander in een andere lidstaat van de Europese Unie, rijst de vraag in hoeverre art. 6:247 lid $2 \mathrm{BW}$ verenigbaar is met het Unierecht, meer in het bijzonder het daarin geregelde internationaal privaatrecht en het discriminatieverbod. Dat speelt met name in de situatie dat de buitenlandse partij de wederpartij is van degene die algemene voorwaarden gebruikt en die buitenlandse partij door art. 6:247 lid 2 BW minder bescherming geniet dan zij zou hebben gehad als zij in Nederland gevestigd zou zijn.
\end{abstract}

Om deze vraag te beantwoorden, illustreren we eerst uitgebreider in welke concrete situatie van zo'n verminderde bescherming sprake is. Vervolgens bespreken we hoe art. 6:247 lid 2 BW zich verhoudt tot het secundaire Unierecht, meer specifiek de Rome I-Verordening, die het toepasselijk recht op overeenkomsten regelt. Daarna onderzoeken we, mede aan de hand van het HR-arrest Van Vliet/Dealkent, ${ }^{2}$ in hoeverre art. 6:247 lid 2 BW verenigbaar is met de verkeersvrijheden uit het primaire Unierecht. Voordat we afsluiten met een voorstel voor aanpassing van de wet, bezien wij of de opgeworpen discussie irrelevant is vanwege de implementatie van de Dienstenrichtlijn. In deze bijdrage gaan we telkens uit van een b2b-koopovereenkomst ${ }^{3}$ en nemen we aan dat de verkoper

\footnotetext{
Mr. L.M. van Bochove is universitair docent internationaal privaatrecht aan de Universiteit Leiden. Mr. T.J. de Graaf is universitair hoofddocent burgerlijk recht aan de Universiteit Leiden en redacteur van dit tijdschrift.

De auteurs danken Herman Speyart voor zijn opmerkingen met betrekking tot een eerdere versie van deze bijdrage.

1. Dit in tegenstelling tot het eerste lid van dat artikel, dat juist bepaalt dat die algemenevoorwaardenafdeling wel van toepassing is op 'overeenkomsten tussen partijen die handelen in de uitoefening van een beroep op bedrijf en die beide in Nederland gevestigd zijn, (...) ongeacht het recht dat de overeenkomst beheerst'.

2. HR 11 mei 2012, ECLI:NL:HR:2012:BW0730, NJ 2012/318 (Van Vliet/Dealkent). Terzijde zij opgemerkt dat rechtbank en hof in deze zaak hadden vastgesteld dat partijen een rechtskeuze hebben gemaakt voor Nederlands recht, met uitsluiting van het Weens Koopverdrag.

3. Hoewel hierna alleen zal worden gesproken over 'verkoper' en 'koper', geldt de hierna verrichte beoordeling ook voor dienstverlening. Omwille van de leesbaarheid en omvang van deze bijdrage concentreren wij ons op koop en zullen wij dienstverlening vooral in voetnoten kort behandelen.
}

degene is die algemene verkoopvoorwaarden gebruikt, en dat de koper een zogeheten kleine wederpartij is in de zin van art. 6:235 BW en dat artikel ook anderszins niet van toepassing is.

\section{Minder bescherming voor koper in andere lidstaat}

Art. 6:247 lid 2 BW heeft tot gevolg dat een koper uit een andere lidstaat minder bescherming geniet dan een koper die in Nederland is gevestigd. Om dit te verduidelijken, beschrijven we eerst de wijze waarop de algemenevoorwaardenafdeling bescherming biedt in geval van een overeenkomst tussen twee in Nederland gevestigde partijen.

Als een professionele verkoper of dienstverlener (hierna voor beide gevallen: verkoper) een offerte stuurt aan een professionele koper of dienstenafnemer (hierna voor beide gevallen: koper), verklaart hij daarin vaak zijn algemene verkoopvoorwaarden van toepassing. Als de koper die offerte vervolgens accepteert, komt een overeenkomst tot stand waarvan de algemene voorwaarden deel uitmaken (art. 6:217 BW). Die voorwaarden bevatten bijna altijd een aansprakelijkheidsuitsluiting of -beperking (hierna: exoneratie) op grond waarvan de verkoper niet of beperkt aansprakelijk is als hij bij de uitvoering van de overeenkomst tekortschiet en de koper daardoor schade lijdt. Zonder een exoneratie zou de verkoper bij wanprestatie (in beginsel) onbeperkt aansprakelijk zijn voor de daardoor geleden schade. Als de verkoper wanpresteert en de koper daardoor schade lijdt, heeft de koper er dus alle belang bij de exoneratie van de verkoper onderuit te halen. Dat kan op een aantal manieren.

Een van de eenvoudigste manieren om een exoneratie onderuit te halen doet zich voor als de verkoper in zijn offerte zijn algemene voorwaarden weliswaar van toepassing verklaart, maar niet meestuurt. Dat zou een schending kunnen opleveren van de in de algemenevoorwaardenafdeling 6.5.3 opgenomen informatieplicht ${ }^{4}$ van art. 6:233 onder b jo. art. 6:234 lid $1 \mathrm{BW}$. Die informatieplicht komt erop neer dat de verkoper, tenzij dat redelijkerwijs niet mogelijk is, zijn algemene voorwaarden actief aan de koper moet verstrekken voordat

4. Hoewel vaak gesproken wordt over een informatieplicht, behelst art 6:233 onder b BW strikt genomen geen rechtens afdwingbare plicht, maar een Obliegenheit, zie Jac. Hijma, Algemene voorwaarden (Mon. BW nr. B55), Deventer: Wolters Kluwer 2016/35. Toch zal, omdat dat nu eenmaal gangbaar is, hierna van een informatieplicht worden gesproken. 
partijen een overeenkomst sluiten (in de meeste gevallen door ze mee te sturen met de offerte). ${ }^{5}$ De bewijslast voor de verstrekking rust op de verkoper. ${ }^{6}$ Als de verkoper zich in zo'n geval niet houdt aan die verplichting, dan kan de koper de hele set algemene voorwaarden van de verkoper vernietigen, ${ }^{7}$ en (dus) ook de daarin opgenomen exoneratie. ${ }^{8}$

Een andere manier om een exoneratie onderuit te halen, is door de exoneratie op grond van art. 6:233 onder a BW te vernietigen omdat zij onredelijk bezwarend is. Dat is echter minder eenvoudig dan vernietigen op grond van niet-tijdige terhandstelling. Bij een beroep op art. 6:233 onder a BW rust de bewijslast dat de betreffende exoneratie onredelijk bezwarend is op de koper, terwijl bij een beroep op art. 6:233 onder b BW de bewijslast dat wel tijdig ter hand is gesteld op de verkoper rust. Ook zullen exoneraties naar onze inschatting eerder op grond van art. 6:248 lid 2 BW buiten toepassing worden gelaten dan dat ze op grond van art. 6:233 onder a BW zullen worden vernietigd. Eerstgenoemd artikel heeft immers een ruimer toepassingsbereik dan laatstgenoemd artikel (omstandigheden voor, bij of na het sluiten van de overeenkomst versus omstandigheden voor of bij het sluiten van de overeenkomst), terwijl de belangrijk(st)e toetsingsomstandigheid 'zwaarte van de schuld' zich in de regel pas na het sluiten van de overeenkomst manifesteert. ${ }^{9}$ En een bespreking van art. 6:248 lid $2 \mathrm{BW}$ in deze bijdrage heeft weinig zin, omdat dat artikel niet in de algemenevoorwaardenafdeling staat en dus niet door art. 6:247 lid 2 BW wordt getroffen. Om die redenen, en omwille van de eenvoud, gebruiken we in deze bijdrage het voorbeeld van vernietiging op grond van niet-tijdige terhandstelling op grond van art. 6:233 onder b BW. Hetgeen we daarover opmerken, is in bepaalde gevallen echter mutatis

5. Omwille van de overzichtelijkheid worden in deze bijdrage (dus) niet besproken gevallen waarin art. 6:247 lid $2 \mathrm{BW}$ in strijd is met de (implementatie van de) Richtlijn 2000/31/EG van het Europees Parlement en de Raad van 8 juni 2000 betreffende bepaalde juridische aspecten van de diensten van de informatiemaatschappij, met name de elektronische han$\mathrm{del}$, in de interne markt (e-commerce-richtlijn) of de Richtlijn 2006/123/EG van het Europees Parlement en de Raad van 12 december 2006 betreffende diensten op de interne markt (Dienstenrichtlijn). Zie daarover uitgebreid o.a. T.J. de Graaf, Naar een coherente(re) implementatie van de informatieplichten met betrekking tot (algemene) voorwaarden voortvloeiend uit de e-commerce-richtlijn en Dienstenrichtlijn, NTBR 2018/24, afl. 6, p. 174-183.

6. HR 11 juli 2008, ECLI:NL:HR:2008:BD1394, NJ 2008/416 (Lommerse-Uitendaal/Atria).

7. HR 17 december 1999, ECLI:NL:HR:1999:AA3876, NJ 2000/140 (Breg/Asper).

8. Die vernietiging heeft o.a. tot gevolg dat de exoneratie nooit heeft gegolden (art. 3:53 BW).

9. Zie uitgebreider T.J. de Graaf, Exoneraties in (ICT-)contracten tussen professionele partijen (diss. Leiden; Recht en Praktijk, deel 141), Deventer: Kluwer 2006, par. 2.2, p. 7-11. Dat neemt niet weg dat de wederpartij er goed aan doet zich primair op vernietiging ex art. 6:233 onder a BW te beroepen en subsidiair op buiten toepassing laten ex art. 6:248 lid 2 BW. De gevolgen van vernietiging (voor verleden, heden en toekomst) zijn immers verstrekkender dan die van het buiten toepassing laten (alleen in het bewuste geval). Dat dat 'primair, subsidiair' mag, blijkt uit HR 14 juni 2002, ECLI:NL:HR:2002:AE0659, NJ 2003/112 (Bramer/Colpro). mutandis van toepassing op vernietiging op grond van art. 6:233 onder a BW.

Terug naar de informatieplicht. Als de koper echter niet in Nederland, maar in een andere lidstaat is gevestigd, dan wordt voldaan aan de voorwaarden van art. 6:247 lid $2 \mathrm{BW}$ en is de algemenevoorwaardenafdeling, inclusief de daarin opgenomen informatieplicht en het daaraan gekoppelde vernietigingsrecht, niet van toepassing. Dit is in het nadeel van de betrokken koper, die daardoor niet meer beschikt over een probaat middel om de exoneratie van tafel te krijgen.

Bovenstaande toont dat art. 6:247 lid 2 BW tot het merkwaardige gevolg leidt dat als een in Nederland gevestigde verkoper zijn algemene voorwaarden niet vóór het sluiten van de overeenkomst aan de koper verstrekt, een in Nederland gevestigde koper de exoneratie van de verkoper wel kan vernietigen, maar een koper die in een andere EU-lidstaat gevestigd is deze mogelijkheid niet heeft. Dit verschil in behandeling roept de vraag op hoe deze bepaling zich verhoudt tot het Unierecht. Is art. 6:247 lid 2 BW verenigbaar met het Unierechtelijke internationaal privaatrecht en met het discriminatieverbod dat voortvloeit uit de verkeersvrijheden? Of is deze bepaling in strijd met het Unierecht en moet zij in intra-unitaire gevallen buiten toepassing worden gelaten?

\section{Verhouding met het unitaire internationaal privaatrecht}

De algemenevoorwaardenafdeling (en dus ook de informatieplicht van art. 6:233 onder b BW) is op grond van art. 6:247 lid 2 BW niet van toepassing op b2b-overeenkomsten tussen partijen die niet beide in Nederland gevestigd zijn, ongeacht of op hun overeenkomst Nederlands recht van toepassing is. De toepasselijkheid van de algemenevoorwaardenafdeling wordt door de wetgever dus losgekoppeld van het op de overeenkomst toepasselijke recht. Deze loskoppeling roept vanuit internationaal privaatrechtelijk perspectief vragen op, in het bijzonder hoe zij zich verhoudt tot de Rome I-Verordening.

De Rome I-Verordening ${ }^{10}$ regelt welk recht van toepassing is op verbintenissen uit een overeenkomst die aanknopingspunten heeft met verschillende landen. De uniforme conflictregels van de verordening gelden voor alle EU-lidstaten, behalve Denemarken. Zoals bekend hebben verordeningen rechtstreekse werking en gaan zij voor op conflictregels uit nationale rechtsbronnen. Dit vloeit voort uit het Unierecht (art. 288, tweede alinea, VWEU) en wordt bevestigd in art. 10:1 BW. De Rome I-Verordening heeft een universeel formeel toepassingsgebied; zij is van toepassing, ongeacht of het recht van een EU-lidstaat wordt aangewezen. Bovendien heeft de Nederlandse wetgever in art. 10:154 BW de Rome I-Verordening van overeenkomstige toepassing verklaard op gevallen die buiten haar materiële werkingssfeer vallen (mits het gaat om

10. Verordening (EG) 593/2008 van het Europees Parlement en de Raad van 17 juni 2008 inzake het recht dat van toepassing is op verbintenissen uit overeenkomst, PbEU 2008, L 177/6. 
verbintenissen uit overeenkomst), waardoor de rol van nationale conflictregels op het terrein van het overeenkomstenrecht vrijwel is uitgespeeld.

Als gevolg van het feit dat de Rome I-Verordening prevaleert boven het nationale recht, mogen de lidstaten op het terrein van het overeenkomstenrecht geen regels hanteren die onverenigbaar zijn met de verordening. $\mathrm{Nu}$ het tweede lid van art. 6:247 BW de toepasselijkheid van de algemenevoorwaardenafdeling loskoppelt van het recht dat de overeenkomst beheerst, dringt de vraag zich op of dit lid op gespannen voet staat met de Rome I-Verordening. Om die vraag te beantwoorden, beoordelen we of toepassing van art. 6:247 lid 2 BW tot andere resultaten leidt dan de toepassing van de Rome IVerordening, en zo ja, of de Rome I-Verordening daartoe de ruimte biedt.

\subsection{Leidt de toepassing van art. 6:247 lid 2 BW tot andere resultaten dan de Rome I-Verordening?}

De conflictregels van de Rome I-Verordening zijn zo geformuleerd dat zij in beginsel één rechtsstelsel van toepassing verklaren op een overeenkomst met grensoverschrijdende aspecten. De overeenkomst wordt dan beheerst door het gehele toepasselijke contractuele regime, zoals dat onder dit rechtsstelsel bestaat. ${ }^{11}$ Wanneer partijen een rechtskeuze uitbrengen overeenkomstig art. 3 Rome I-Verordening en voldaan is aan het internationaliteitsvereiste van art. 1 lid 1 Rome IVerordening, dan komt het gekozen recht in de plaats van zowel de dwingende als de aanvullende bepalingen van het recht van het land dat van toepassing zou zijn geweest bij gebreke van een rechtskeuze. Bij gebreke van een rechtskeuze zal het toepasselijk recht op een internationale b2b-overeenkomst worden bepaald op grond van art. 4 Rome IVerordening, dat bijvoorbeeld voor koopovereenkomsten verwijst naar het overeenkomstenrecht van het land waar de verkoper zijn gewone verblijfplaats heeft. ${ }^{12}$

Wanneer de conflictregels van de Rome I-Verordening verwijzen naar Nederlands recht (bijvoorbeeld omdat sprake is van een rechtskeuze of omdat de verkoper zijn gewone verblijfplaats heeft in Nederland) is dus in beginsel het gehele Nederlandse (overeenkomsten)recht van toepassing. Zoals gezegd bepaalt art. 6:247 lid 2 BW echter dat de algemenevoorwaardenafdeling niet van toepassing is op een overeenkomst tussen twee professionele partijen die niet allebei in Nederland zijn gevestigd, ook wanneer de overeenkomst wordt beheerst door Nederlands recht. Art. 6:247 lid 2 BW schakelt dus een deel van het volgens de Rome I-Verordening toepasselijke Nederlandse recht uit. De vraag rijst of de Rome I-Verordening hiervoor ruimte biedt.

\footnotetext{
11. Asser/Kramer \& Verhagen 10-III 2015/749. Zie art. 12 Rome IVerordening voor een niet-uitputtende lijst van onderwerpen waarop dit rechtsstelsel van toepassing is.

12. Zie art. 4 lid 1 onder a Rome I-Verordening.
}

\subsection{Biedt de Rome I-Verordening ruimte voor de uitschakeling van de algemenevoorwaardenafdeling?} In een deel van de literatuur ${ }^{13}$ wordt de algemenevoorwaardenafdeling aangemerkt als 'voorrangsregels', oftewel bepalingen van bijzonder dwingend recht in de zin van art. 9 Rome IVerordening. In dat geval kan een deel van het op de overeenkomst overigens toepasselijke recht worden doorkruist. Voorrangsregels zijn bepalingen 'aan de inachtneming waarvan een land zoveel belang hecht voor de handhaving van zijn openbare belangen zoals zijn politieke, sociale of economische organisatie, dat zij moet[en] worden toegepast op elk geval dat onder de werkingssfeer ervan valt'. ${ }^{14}$

Art. 9 lid 2 Rome I-Verordening biedt een grondslag voor de toepassing van voorrangsregels van de wetgeving van de aangezochte rechter (de lex fori) in gevallen die onder hun toepassingsbereik vallen, ongeacht welk recht overigens op de overeenkomst van toepassing is. Art. 6:247 BW wordt in dit verband beschouwd als scope rule, die het toepassingsbereik van de algemenevoorwaardenafdeling aangeeft. ${ }^{15}$ Ook in de parlementaire geschiedenis met betrekking tot de algemenevoorwaardenafdeling wordt een direct verband gelegd tussen art. 6:247 BW en het leerstuk van de voorrangsregels, waarbij wordt verwezen naar art. 7 van het destijds nog niet in werking getreden $\mathrm{EVO}^{16}$ - de voorganger van art. 9 Rome IVerordening. ${ }^{17}$

Er zijn echter verschillende redenen om te betwijfelen dat art. 6:247 lid 2 BW kan worden toegepast via art. 9 Rome IVerordening. Zo is art. 9 lid 1 Rome I-Verordening positief geformuleerd: het spreekt van het belang van een staat bij inachtneming van de bepaling in kwestie. Uit de parlementaire geschiedenis van art. 6:247 lid 2 BW vloeit voort dat Nederland in internationale gevallen juist belang hecht aan het niet toepassen van de algemenevoorwaardenafdeling. Daar komt bij dat op basis van de parlementaire geschiedenis moet worden aangenomen dat art. 6:247 lid $2 \mathrm{BW}$ geen dwingend recht is; partijen die niet beide in Nederland zijn gevestigd, kunnen er immers voor kiezen de algemenevoorwaardenafdeling expliciet van toepassing te verklaren en daarmee art. 6:247 lid 2 BW buiten werking stellen. ${ }^{18}$ Als Nederland een dusdanig groot belang zou toekennen aan het buiten toepassing laten van de algemenevoorwaardenregeling in internationale gevallen, dan

13. P. Vlas, Internationaal privaatrecht in de spiegel van het nieuwe BW (oratie Amsterdam VU), Deventer: Kluwer 1989, p. 8. Anders: Hondius, in: GS Verbintenissenrecht, art. 6:247 BW, aant. 7 (bijgewerkt 15 juni 2019), die alleen lid 1 en 4 van art. 6:247 BW als voorrangsregels aanmerkt.

14. Zie art. 9 lid 1 Rome I-Verordening.

15. Zie ook J.W. Westenberg, Een scope-rule met een Januskop. Artikel 6.5.2A.13 NBW onder de loep, NJB 1987, afl. 15, p. 463.

16. Verdrag inzake het recht dat van toepassing is op verbintenissen uit overeenkomst van 19 juni 1980, Trb. 1980, 156.

17. Zie Parl. Gesch. Boek 6 (Inv. 3, 5 en 6), p. 1812: 'Het onderhavige [art. 6:247 BW; LvB \& TdG] bestempelt afdeling [6.5.3; LvB \& TdG] tot zodanige in artikel 7 [EVO; LvB \& TdG] bedoelde regels, indien aan de in de leden 1-4 gestelde vereisten is voldaan.'

18. Parl. Gesch. Boek 6 (Inv. 3, 5 en 6), p. 1815. Zie ook Vlas 1989, p. 7 en Asser/Sieburgh 6-III 2018/511 
had het voor de hand gelegen om art. 6:247 lid 2 BW juist wél als dwingend recht aan te merken. Op grond van het voorgaande menen wij dat art. 6:247 lid 2 BW niet als een aan een voorrangsregel gekoppelde scope rule kan worden aangemerkt. Art. 9 Rome I-Verordening kan daarom niet als grondslag worden gebruikt om toe te staan dat art. 6:247 lid 2 BW de algemenevoorwaardenafdeling buiten werking stelt als op een internationale b2b-overeenkomst Nederlands recht van toepassing is.

Bovengenoemde problemen worden vermeden wanneer art. 6:247 lid 2 BW als een afbakeningsregel van het op de overeenkomst toepasselijke recht (de lex causae) wordt aangemerkt. ${ }^{19}$ Volgens deze zienswijze moeten twee stappen worden onderscheiden. De eerste stap houdt in dat aan de hand van de Rome I-Verordening wordt bepaald welk recht van toepassing is op de overeenkomst. Wanneer op grond van de verordening het Nederlandse recht van toepassing is, dan volgt stap twee: de toepassing van het Nederlandse recht, inclusief art. 6:247 lid $2 \mathrm{BW}$. Zodra een van de partijen buiten Nederland gevestigd is, schakelt deze bepaling de algemenevoorwaardenafdeling uit, waarna moet worden teruggevallen op de algemene regels van Nederlands overeenkomstenrecht. In deze benadering is art. 6:247 lid $2 \mathrm{BW}$ wél verenigbaar met de Rome I-Verordening.

Ook als art. 6:247 lid 2 BW verenigbaar wordt geacht met de Rome I-Verordening (als afbakeningsregel van de lex causae of toch via art. 9 Rome I-Verordening), betekent dat echter nog niet dat de bepaling vanuit EU-rechtelijk perspectief door de beugel kan. ${ }^{20}$ In het vervolg van deze bijdrage wordt onderzocht hoe art. 6:247 lid $2 \mathrm{BW}$ zich verhoudt tot het primaire Unierecht, meer in het bijzonder met het discriminatieverbod dat voortvloeit uit de verkeersvrijheden.

\section{Discriminerende werking}

Een bekend voorbeeld waarin art. 6:247 lid 2 BW door de Hoge Raad werd toegepast, is zoals gezegd de zaak Van Vliet/ Dealkent. Die zaak komt kort gezegd op het volgende neer. Het in Nederland gevestigde Van Vliet verkocht in februari 2001, onder toepasselijkverklaring van haar algemene voorwaarden, oude legervoertuigen aan de in het Verenigd Koninkrijk gevestigde vennootschap Dealkent. Tijdens een inspectie op 6 april 2001 bleken de voertuigen non-conform te zijn. Van Vliet stuurde op 3 mei 2001 haar algemene voorwaarden naar Dealkent. Rechtbank en hof oordelen dat dat te laat was en ontzegden Van Vliet een beroep op haar algemene voorwaarden (met daarin een exoneratie). In het oordeel van het hof las de Hoge Raad dat Dealkent zich beriep op schending van de informatieplicht in art. 6:233 onder b jo. art. 6:234 BW en dat het hof dat beroep gegrond heeft verklaard. Het cassatiemiddel klaagde er onder andere over dat het hof heeft miskend dat de algemenevoorwaardenafdeling 6.5.3 niet

19. Vgl. Asser/Kramer \& Verhagen 10-III 2015/75.

20. Zie in het kader van de voorrangsregels HvJ EU 17 oktober 2013, C-184/12, ECLI:EU:C:2013:663 (Unamar), r.o. 46. van toepassing is op grond van art. 6:247 lid 2 BW. De Hoge Raad verklaarde die klacht gegrond.

Echter, als Dealkent in Nederland gevestigd zou zijn geweest, zou de algemenevoorwaardenafdeling op grond van art. 6:247 lid $1 \mathrm{BW}$ wel van toepassing zijn geweest, en had zij de algemene voorwaarden ex art. 6:233 onder b jo. art. 6:234 lid 1 BW wel kunnen vernietigen wegens niet-tijdige terhandstelling. Anders gezegd, het enkele feit dat Dealkent in het Verenigd Koninkrijk was gevestigd, heeft haar deze aan een Nederlandse koper toekomende vernietigingsmogelijkheid ontnomen. ${ }^{21}$ Hiermee is sprake van ongelijke behandeling: een buitenlandse koper geniet niet dezelfde bescherming als een Nederlandse. De vraag rijst of Dealkent, als een (toen nog) in een EU-lidstaat gevestigde koper, buitenwerkingstelling van art. 6:247 lid 2 BW of toepassing van de algemenevoorwaardenafdeling had kunnen afdwingen met een beroep op de in de verkeersvrijheden opgenomen discriminatieverboden. ${ }^{22}$

Om dit te kunnen bepalen, moet worden vastgesteld of de verkeersvrijheden hier van toepassing zijn (par. 4.1), of hier sprake is van een beperkende maatregel (par. 4.2), dan wel van een rechtvaardigingsgrond (par. 4.3), en wat de gevolgen zijn van de vaststelling dat sprake is van een belemmering van een verkeersvrijheid (par. 4.4).

\subsection{Binnen de werkingssfeer van de verkeersurijheden?}

Het feitencomplex van Van Vliet/Dealkent valt onder het vrij verkeer van goederen. De legervoertuigen uit deze zaak kwalificeren namelijk als goederen in de zin die het Hof van Justitie van de EU eraan geeft: waren die op geld waardeerbaar zijn en die als zodanig het voorwerp vormen van een transactie. ${ }^{23}$ Ook is voldaan aan het vereiste van grensoverschrijdendheid van het verkeer, aangezien sprake is van verkoop door een verkoper die zijn zetel heeft in een lidstaat (Nederland) aan een koper die zijn zetel heeft in een andere lidstaat (Verenigd Koninkrijk).

$\mathrm{Nu}$ de zaak de export van goederen betreft, valt zij in beginsel onder de reikwijdte van art. 35 VWEU, dat een verbod bevat

21. Overigens zou Dealkent in dat geval ook geen beroep zijn toegekomen op het vernietigingsrecht ten aanzien van individuele bedingen die onredelijk bezwarend zijn (art. 6:233 onder a BW) en zou zij ook om die reden benadeeld zijn.

22. Wij hebben het hier over de verkeersvrijheden en niet over het algemene non-discriminatiebeginsel van art. $18 \mathrm{VWEU}$, omdat dat algemene beginsel de uitdrukking is van een lex generalis die voor de verkeersvrijheden wordt uitgewerkt in het deel van het VWEU over de interne markt. Als een maatregel een beperking van een verkeersvrijheid oplevert, moet hij naar vaste rechtspraak onder die specialis worden beoordeeld, en niet onder de generalis van art. 18 VWEU; zie bijv. HvJ EG 3 juli 1979, ECLI:EU:C:1979:177, gevoegde zaken 185/78 t/m 204/78, SEW 1980, p. 293 m.nt. C.W.A. Timmermans (Van Dam en zonen), r.o. 10.

23. HvJ EG 10 december 1968, C-7/68, ECLI:EU:C:1968:51 (Commissie/ Italië). B2b-diensten zullen over het algemeen worden aangemerkt als diensten in de zin van art. 57, eerste alinea, VWEU: 'de dienstverrichtingen welke gewoonlijk tegen vergoeding geschieden, voorzover de bepalingen, betreffende het vrije verkeer van goederen, kapitaal en personen op deze dienstverrichtingen niet van toepassing zijn'. 
op ' $[\mathrm{k}]$ wantitatieve uitvoerbeperkingen en alle maatregelen van gelijke werking' ${ }^{24}$

\subsection{Beperkende maatregel?}

Aangezien art. 6:247 lid 2 BW geen kwantitatieve uitvoerbeperking behelst, rijst de vraag of dat artikel een maatregel van gelijke werking in de zin van art. 35 VWEU is. Volgens de bekende Dassonville-regel valt iedere nationale maatregel hieronder die de handel tussen de lidstaten al dan niet rechtstreeks, daadwerkelijk of potentieel kan belemmeren. ${ }^{25}$ Het gaat daarbij om maatregelen die de uitvoer uit een lidstaat moeilijker maken dan het verkeer van goederen in de interne situatie van de betrokken lidstaat. ${ }^{26}$ De beperkende gevolgen voor het handelsverkeer kunnen zelfs gering zijn, op voorwaarde dat zij noch te onzeker, noch te indirect zijn. ${ }^{27}$ Daarbij heeft het Hof van Justitie uitgemaakt dat die bepalingen ook van toepassing zijn als de betrokken beperking haar neerslag vindt bij de ontvanger. ${ }^{28}$

Ons inziens kwalificeert art. 6:247 lid 2 BW als maatregel van gelijke werking in de zin van art. 35 VWEU. Het artikel maakt immers onderscheid tussen interne en grensoverschrijdende situaties, en daarmee wordt de in het buitenland gevestigde koper in een nadeliger positie gebracht dan de in Nederland gevestigde koper. Niet ter zake doet of buitenlandse kopers in de praktijk maatregelen kunnen nemen om de regel van art. 6:247 lid 2 BW te omzeilen, bijvoorbeeld door met de verkoper overeen te komen dat art. 6:247 lid 2 BW buiten toepassing wordt verklaard, zodat de algemenevoorwaardenafdeling wél van toepassing is. ${ }^{29}$ Ook doet niet ter zake of buitenlandse kopers hun inkopen daadwerkelijk laten afhangen van de werking van art. 6:247 lid $2 \mathrm{BW}$ en als gevolg van dit artikel eerder in plaats van de Nederlandse verkoper een buitenlandse concurrent verkiezen wiens wetgeving wel van hem eist dat hij zijn algemene voorwaarden voor het sluiten van de overeenkomst aan de ander verstrekt. Voldoende is immers dat art. 6:247 lid 2 BW potentieel de handel tussen lidstaten beperkt, zelfs als het effect gering is. Dat is ook logisch. Het discriminatoire karakter van een maatregel kan niet worden gerechtvaardigd door het argument dat degene die gediscrimineerd wordt de confrontatie aan moet gaan, zijn heil elders moet gaan zoeken of er nauwelijks hinder van ondervindt. Evenmin is relevant dat de Nederlandse verkopers die exporteren daar voordeel van hebben. Het discrimineren

24. Bij diensten voorziet art. $56 \mathrm{VWEU}$ in een voor de doeleinden van deze bespreking identiek beperkingsverbod.

25. HvJ EG 11 juli 1974, C-8/74, ECLI:EU:C:1974:82 (Dassonville), r.o. 5.

26. HvJ EG 8 november 1979, C-15/79, ECLI:EU:C:1979:253, NJ 1980/470 (Groenveld), r.o. 7.

27. Zie o.a. HvJ EU 28 februari 2018, C-518/16, ECLI:EU:C:2018:126 (ZPT), r.o. 44.

28. Zie voor diensten: HvJ EG 2 februari 1989, C-186/87, ECLI:EU:C: 1989:47 (Cowan), r.o. 15. Voor goederen geldt hetzelfde.

29. Vgl. Asser/Hartkamp 3-I 2019/37, waarin wordt betoogd dat wanneer regels van nationaal recht aan de verkeersvrijheden worden getoetst, gelet moet worden 'op de inhoud van de regel en zijn (potentieel) belemmerende werking op de uitoefening van de vrijheden, niet op de vraag of zijn toepasselijkheid in theorie "weggecontracteerd" had kunnen worden'. van de een kan niet worden gerechtvaardigd door het argument dat een ander daar voordeel van geniet.

\subsection{Rechtvaardigingsgrond?}

Uitvoerbeperkingen kunnen onder omstandigheden gerechtvaardigd zijn. Art. 36 VWEU bevat een limitatieve opsomming van de gronden van algemeen belang die een belemmering van het vrij verkeer van goederen kunnen rechtvaardigen, waaronder gezondheid en openbare veiligheid. Uit de parlementaire geschiedenis blijkt dat art. 6:247 lid $2 \mathrm{BW}$ is opgenomen ter bevordering van een vlot handelsverkeer. ${ }^{30}$ Hoewel kan worden betoogd dat hiermee een algemeen belang is gemoeid, wordt een vlot handelsverkeer niet genoemd in art. $36 \mathrm{VWEU}$ en levert het dus geen geschreven rechtvaardigingsgrond op.

Naast de geschreven verdragsexcepties worden in rechtspraak van het Hof van Justitie rule of reason-uitzonderingen erkend, die inhouden dat een beperking onder omstandigheden kan worden gerechtvaardigd op grond van 'dwingende redenen van algemeen belang. ${ }^{31}$ Ook deze uitzondering biedt echter geen soelaas; zij kan bij goederen slechts worden ingeroepen bij niet-discriminatoire beperkingen. ${ }^{32}$

\subsection{Gevolgen van strijd met de verkeersvrijheden?}

Omdat art. 6:247 lid 2 BW een door een lidstaat (Nederland) uitgevaardigde beperkende maatregel is, kan de betrokken koper die gevestigd is in een andere lidstaat zich in rechte beroepen op strijd van die bepaling met de verkeersvrijheden, die zich traditioneel juist richten tot de lidstaten. Aangezien de koper niet het gedrag van de verkoper aan de orde stelt, maar een wettelijke bepaling, is geen sprake van (bij de verkeersvrijheden niet zonder meer bestaande) horizontale rechtstreekse werking, maar van (wel geoorloofde) verticale werking die effecten heeft op een horizontale verhouding. ${ }^{33}$ Omdat art. 6:247 lid 2 BW, zoals hierboven is beargumenteerd, strijd oplevert met de verkeersvrijheden, zal de rechter de bepaling buiten toepassing moeten laten. ${ }^{34}$ De koper kan

30. Parl. Gesch. Boek 6 (Inv. 3, 5 en 6), p. 1807.

31. HvJ EG 16 december 2008, C-205/07, ECLI:EU:C:2008:730 (Gysbrechts), r.o. 45 .

32. Bij diensten geldt niet de beperking dat de 'rule of reason'-uitzondering slechts kan worden ingeroepen bij niet-discriminatoire beperkingen. Daardoor is bij diensten de vraag relevant of sprake is van 'dwingende redenen van algemeen belang' die de beperkingen in art. 6:247 lid 2 BW rechtvaardigen. Die dwingende redenen zien wij niet. Aangezien de interne markt moet worden gezien als een ruimte zonder binnengrenzen, die gelijk kan worden gesteld met een enkele nationale economische markt, zien wij niet in waarom ondernemers in een zuiver binnenlandse situatie aan andere regels gebonden moeten worden dan in een grensoverschrijdende situatie waarin beide partijen in een lidstaat zijn gevestigd. In het kader van deze bijdrage voert het te ver dit verder uit te werken, temeer omdat strijd van art. 6:247 lid 2 BW met het Unierecht in een koopsituatie al voldoende reden oplevert dat artikel aan te passen, ook al mocht er in een dienstensituatie desondanks geen sprake zijn van strijd met het Unierecht.

33. Zie Asser/Hartkamp 3-I 2019/57.

34. HvJ EG 9 maart 1978, C-106/77, ECLI:EU:C:1978:49 (Simmenthal II), r.o. 24. 
op deze wijze dus de toepassing van de algemenevoorwaardenafdeling afdwingen.

\section{Vrij dienstenverkeer: discussie irrelevant vanwege de (implementatie van de) Dienstenrichtlijn?}

Wat de diensten betreft moet ook nog worden onderzocht wat het effect is van de Dienstenrichtlijn. Zo wijst Loos erop dat art. 6:247 lid 2 BW niet van toepassing is op de buiten de algemenevoorwaardenafdeling opgenomen informatieplicht van art. 6:230c jo. art. 6:230e BW, die dienen ter implementatie van de Dienstenrichtlijn. ${ }^{35}$ Die informatieplicht van art. 6:230b onder 6 jo. art. 6:230c jo. art. 6:230e BW (hierna: de diensteninformatieplicht) verplicht de dienstverrichter die een dienst in de zin van de Dienstenrichtlijn aanbiedt of verricht (zie de definities opgenomen in art. 6:230a BW) zijn algemene voorwaarden op de in art. 6:230c BW bedoelde wijze te verstrekken of beschikbaar te stellen op het in art. 6:230e BW bedoelde moment.

Het feit dat de algemene voorwaarden op grond van de diensteninformatieplicht hoe dan ook verstrekt moeten worden, betekent echter niet - en zo begrijpen wij Loos overigens ook niet - dat de vraag of art. 6:247 lid 2 BW in strijd is met een discriminatieverbod wat dienstenovereenkomsten betreft irrelevant is. Die uit de Dienstenrichtlijn afkomstige informatieplicht is immers, zoals gezegd, alleen van toepassing op een dienstverrichter die een dienst in de zin van de Dienstenrichtlijn aanbiedt of verricht. Hoewel het Hof van Justitie een ruime definitie aan het begrip 'dienst' in de zin van deze richtlijn heeft gegeven, waardoor ook bepaalde vormen van verkoop van goederen hieronder kunnen vallen, ${ }^{36}$ zijn er ook activiteiten waarop de Dienstenrichtlijn niet van toepassing is. ${ }^{37}$ In die situaties is de diensteninformatieplicht niet van toepassing en is het dus wel degelijk relevant te beoordelen of de informatieplicht ex art. 6:233 onder b BW ondanks het in art. 6:247 lid 2 BW bepaalde van toepassing is in het licht van de verkeervrijheden.

Ook is onduidelijk wat de sanctie is als de diensteninformatieplicht niet wordt nageleefd. Het BW verklaart de diensteninformatieplicht niet van dwingend recht en verbindt er geen bijzondere sanctie aan. Misschien is er wel helemaal geen afzonderlijke sanctie voor schending van de diensteninformatieplicht, maar vindt sanctionering alleen plaats als de informatieplicht van art. 6:233 onder b jo. art. 6:234 BW is geschonden. Onlogisch is die gedachte niet. Art. 6:234 lid 1 BW verwijst immers met zoveel woorden naar art. 6:230c BW als een van de mogelijkheden om aan de informatieplicht te voldoen. Daaruit zou kunnen worden geconcludeerd dat schending van de diensteninformatieplicht enkel via de vernie-

35. M.B.M. Loos, Algemene voorwaarden, Den Haag: Boom juridisch 2018, nr. 32.

36. HvJ EU 30 januari 2018, C-360/15, ECLI:EU:C:2018:44 (Gemeente Appingedam), r.o. 84-97. Zie ook De Graaf 2018, p. 178-179.

37. Bijv. omdat sprake is van een van de uitgezonderde activiteiten die worden genoemd in art. 2 lid 2 Dienstenrichtlijn. tigingssanctie van art. 6:233 onder b BW plaats dient te vinden en dat als art. 6:233 onder b BW niet van toepassing is, schending van de diensteninformatieplicht dus niet wordt gesanctioneerd. De literatuur pleit echter wel voor een afzonderlijke sanctie. Zo denkt Valk aan verschillende mogelijke sancties (nakoming, schadevergoeding, uitleg en vernietiging wegens dwaling) ${ }^{38}$ en denken Hijma en De Graaf aan vernietiging door analoge toepassing van art. 6:233 onder b BW. ${ }^{39}$

Gelet op het hiervoor behandelde verschil in toepassingsbereik tussen beide informatieplichten en de onduidelijkheid over of, en zo ja hoe, niet-naleving van art. $6: 230 \mathrm{~b}$ onder $6 \mathrm{BW}$ gesanctioneerd is, menen wij dat het wel degelijk relevant is te beoordelen of art. 6:247 lid 2 BW in strijd is met het Unierechtelijk internationaal privaatrecht en de verkeersvrijheden.

\section{Conclusie en wijzigingsvoorstel}

Bovenstaande analyse laat zien dat het tweede lid van art. 6:247 BW vanuit EU-rechtelijk perspectief problematisch is. Hoewel deze bepaling zich met enige creativiteit nog wel laat verenigen met de Rome I-Verordening, geldt dat niet voor het VWEU: art. 6:247 lid 2 BW maakt een niet-gerechtvaardigd onderscheid op basis van de gewone verblijfplaats van de koper en is daarmee in strijd met het discriminatieverbod dat voortvloeit uit de verkeersvrijheden. ${ }^{40}$ Teneinde de spanning met het Unierecht op te heffen, stellen wij voor aan art. 6:247 lid 2 BW de volgende, gecursiveerde zinsnede toe te voegen:

'Op overeenkomsten tussen partijen die handelen in de uitoefening van een beroep of bedrijf en die niet beide in de $E U$ gevestigd zijn, is deze afdeling niet van toepassing, ongeacht het recht dat de overeenkomst beheerst.'

38. Valk, in: T\&C Vermogensrecht 2019, art. 6:230b BW, aant. sanctionering binnen het privaatrecht.

39. Hijma 2016/41 en De Graaf 2018, p. 180-181.

40. Vgl. ook O. Remien, Zwingendes Vertragsrecht und Grundfreiheiten des EG-Vertrags (Habilitationsschrift Hamburg), Tübingen: Mohr Siebeck 2003, p. 494, waarnaar Asser/Hartkamp 3-I 2019/35 verwijst bij de behandeling van het Europese discriminatieverbod. Zie ook H.N. Schelhaas, Algemene voorwaarden in handelstransacties (Studiekring 'Prof. mr. J. Offerhaus', nieuwe reeks nr. 13), Deventer: Kluwer 2011, nrs. 2.2, 5.3 en 7.3, die om andere redenen bepleit dat de informatieplicht van art. $6: 233$ onder b BW met bepaalde restricties ook voor internationale transacties geldt. 